\title{
PERTUMBUHAN DAN SINTASAN LARVA KERANG MUTIARA Pinctada maxima PADA SUMBER PAKAN BERBEDA
}

\author{
(Growth and Survival of Pearl Oyster Pinctada maxima Larvae at Food Source)
}

\author{
Frista P. Tarigan ${ }^{1 *}$, Stenly Wullur ${ }^{1 *}$, Veibe Warouw ${ }^{1}$, Inneke F.M. Rumengan ${ }^{1}$, \\ Elvy L. Ginting ${ }^{1}$, Cysca Lumenta ${ }^{2}$.
}

1. Program Studi IImu Kelautan, Fakultas Perikanan dan Ilmu Kelautan, Universitas Sam Ratulangi, Manado.

2. Program Budidaya Perairan, Fakultas Perikanan dan IImu Kelautan, Universitas Sam Ratulangi, Manado.

*e-mail : fristaperdanatarigan@yahoo.com, stenlywullur@unsrat.ac.id

This study aims to measure growth and determine the survival of pearl oyster Pinctada Maxima larvae cultured at different feed sources, i.e raw fish feed (feed preparation follows the procedure in patent (No. P00201609066 and P14201802692) which has undergone immersion in several probiotic products (such as: EM4, Probio FM and Starbio F9), microalgae and larvae without feeding as control. The pearl oyster larvae used in the present study were 14 days old larvae taken from PT.Arthe Samudra, Bitung, North Sulawesi. Larvae were cultured using plastic containers containing $\pm 700 \mathrm{ml}, 35 \mathrm{ppt} \mathrm{sea}$ water which was aerated at a speed of about $\pm 0.66 \mathrm{ml}$ / minute. Larvae were then cultured for 14 days using different feed sources according to the treatment in triplicate. The larvae were sampled every 2 days and their length, height and base were measured. At the end of the study, the larvae in all treatments were harvested and the number of larvae was calculated to determine larva survival in each treatment. The results of measurements of length $(61.9-194.47 \mu \mathrm{m})$, height $(59.46-216.81 \mu \mathrm{m})$ and base width of larvae $(21-88.1 \mu \mathrm{m})$ showed a stable growth patterns in larvae fed raw fish and microalgae compared to the larvae in treatment without feed. The highest survival rate was found in larvae fed microalgae (102 \pm 121.7 larvae), then larvae on raw fish immersed in several probiotic products; Starbio F9 ( $29 \pm 18.02$ larvae), Probio FM (5.6 \pm 1.52 larvae) and EM 4 (1.66 \pm 1 larvae).

Keywords : Meroplankton, Pinctada maxima, Probiotic

Penelitian ini bertujuan mengukur pertumbuhan dan menentukan sintasan larva kerang mutiara yang dipelihara pada sumber pakan berbeda, yaitu pakan ikan mentah (penyiapan pakan mengikuti prosedur pada paten No. P00201609066 dan P14201802692) yang telah melalui proses perendaman pada beberapa produk probiotik (seperti: EM4, Probio FM, dan Starbio F9), mikroalga dan larva tanpa pemberian pakan sebagai kontrol. Larva kerang mutiara yang digunakan adalah larva yang telah berumur 14 hari, diambil dari PT.Arthe Samudra, Bitung, Sulawesi Utara. Larva dipelihara menggunakan wadah palstik berisi $\pm 700 \mathrm{ml}$ air laut $35 \mathrm{ppt}$ yang berisi aerasi dengan kecepatan sekitar $\pm 0.66 \mathrm{ml} /$ menit. Larva kemudian dipelihara selama 14 hari menggunakan sumber pakan berbeda sesuai dengan perlakuan dengan 3 kali pengulangan. Setiap 2 hari sekali diambil sebanyak $\pm 3 \mathrm{ml}$ cuplikan sampel dan larva yang ada dalam cuplikan diukur bagian panjang, tinggi, dan pangkal larva. Pada akhir penelitian, larva dalam semua perlakuan dipanen dan jumlah larva dihitung untuk menentukan sintasan larva pada masingmasing perlakuan. Hasil pengukuran panjang $(61.9-194.47 \mu \mathrm{m})$, tinggi $(59.46-216.81 \mu \mathrm{m})$ dan lebar pangkal cangkang $(21-88.1 \mu \mathrm{m})$ menunjukkan adanya pola pertumbuhan yang cenderung lebih stabil pada larva yang diberi pakan ikan mentah yang telah direndam dengan beberapa produk probiotik dan pada perlakuan pemberian pakan mikroalga dibanding pada perlakuan tanpa pakan. Adapun sintasan larva tertinggi terdapat pada larva yang diberi pakan mikroalga (102 \pm 121.7 larva), kemudian larva pada pakan ikan mentah yang direndam pada beberapa produk probiotik; F9 ( $29 \pm 18.02$ larva), Probio FM ( $5.6 \pm 1.52$ larva) dan EM 4 (1.66 \pm 1 larva).

Kata kunci : Meroplankton Larva, Pinctada maxima, Probiotik 


\section{PENDAHULUAN}

Jenis kerang ini hidup di perairan laut sekitar terumbu karang, lamun, mangrove, serta dapat hidup di ekosistem laut dalam (Ponder dan Lindberg, 2008). Beberapa jenis kerang yang dapat menghasilkan mutiara, antara lain Pinctada margaritifera, Pinctada maxima, Pinctada fucata, Pteria sternia, dan Pteria penguin. Jenis kerang penghasil mutiara yang dikembangkan di Indonesia adalah jenis dari Pinctada maxima, Pinctada margaritifera, dan Pinctada penguin (Winanto, 2004).

Pemeliharaan kerang mutiara di Indonesia mulai berkembang semenjak tahun 2000, yang ditandai dengan adanya hatchery (panti pembenihan) kerang mutiara, yang umumnya dimiliki oleh pengusaha lokal dan dikerjakan oleh tenaga domestik (Sujoko, 2010). Perkembangan budidaya dan permintaan kerang mutiara kemudian menjadi salah satu penyebab meningkatnya permintaan akan spat (juvenil) kerang mutiara. Hingga saat ini, ketersediaan spat masih sangat terbatas, dan sering dipengaruhi oleh musim, sehingga sebagian besar usaha budidaya mutiara mengandalkan pengumpulan spat dari alam. Akibatnya, pengambilan spat dari alam yang dilakukan terus-menerus berakibat pada semakin kurangnya ketersediaan spat di alam (Winanto, 2004).

Pemberian pakan pada larva kerang mutiara, pada prinsipnya hendaknya memiliki ukuran yang sesuai dengan bukaan mulut larva, cepat dicerna, mengandung nilai nutrisi tinggi, dapat dikultur secara massal, cepat tumbuh dengan kepadatan yang tinggi dan tidak menghasilkan substansi racun (Ponis et al., 2006 dalam Winanto., 2009).

Sebagai sumber makanan utamanya, namun pemeliharaan mikroalga sebagai sumber pakan kerang mutiara membutuhkan biaya investasi dan biaya operasional yang mahal. Penelitian sebelumnya oleh beberapa peneliti (Wullur et al., 2009), menunjukkan bahwa plankton termasuk rotifer, dapat menggunakan mikroalga ataupun bakteri sebagai sumber nutrisinya. Peranan bakteri terhadap rotifer menunjukkan pengaruh yang signifikan dalam pertumbuhan dan perkembangan rotifer.

Penelitian ini bertujuan untuk menguji-coba penggunaan sumber nutrisi berbasis bakteri hasil penguraian ikan mentah, sebagai alternatif sumber nutrisi konvensional berbasis mikroalga dalam pemeliharaan larva kerang mutiara. Adapun yang menjadi tujuan khusus penelitian ini adalah :

1. Mengukur pertumbuhan larva kerang mutiara yang dipelihara menggunakan pakan ikan mentah yang telah melalui proses perendaman produk probiotik, pakan mikroalga dan tanpa pakan.

2. Menentukan sintasan larva kerang mutiara yang dipelihara yang menggunakan limbah perikanan yang dikombinasikan dengan beberapa jenis produk bakteri probiotik dan yang menggunakan pakan murni dan tanpa pemberian pakan.

\section{METODE PENELITIAN}

\section{Tempat dan Waktu Penelitian}

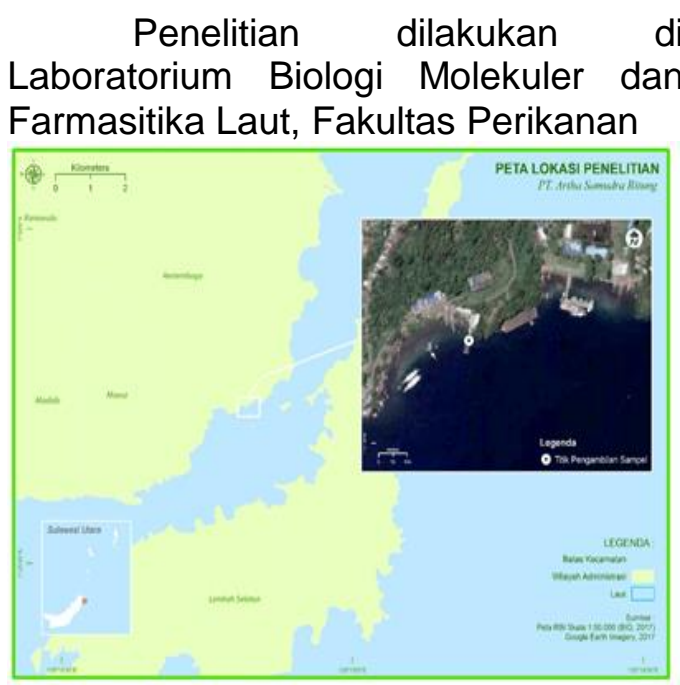

Gambar 1.Peta Lokasi Pengambilan Sampel Sumber: Citra satelit (Google map) (2018), 
dan IImu Kelautan, UNSRAT Manado. Sampel larva kerang mutiara yang digunakan diambil dari perusahaan budidaya kerang di PT.Artha Samudera, Bitung, Sulawesi Utara. telah diolah kembali. Sampel larva yang digunakan adalah larva yang telah berumur sekitar 14 hari. Adapun waktu penelitian dilakukan selama 3 bulan.

\section{Persiapan Penelitian}

Penelitian ini diawali dengan dengan melakukan pengambilan sampel larva kerang mutiara di PT. Artha Samudera, Bitung. Perusahaan ini merupakan pemasok larva kerang mutiara di berbagai fasilitas budidaya kerang mutiara di wilayah Indonesia bagian timur.

Adapun larva yang digunakan dalam penelitian adalah larva kerang mutiara yang berumur 14 hari setelah ditetaskan. Larva kerang mutiara tersebut diambil langsung dari bak penampungan larva kerang, dengan menggunakan jaring plankton yang berukuran 60 dan $100 \mu \mathrm{m}$. Larva kerang mutiara yang terkumpul, kemudian dipindahkan ke dalam wadah plastik (volume $1500 \mathrm{ml}$ ), yang sebelumnya telah diisi dengan air laut bersalinitas 35 ppt. Air laut yang digunakan tersebut adalah air laut yang sama dengan air laut yang digunakan dalam pemeliharaan sampel kerang mutiara yang digunakan dalam penelitian ini. Larva kerang mutiara tersebut, selanjutnya dibawa ke Laboratorium Biologi Molekuler dan Farmasitika Laut, Fakultas Perikanan dan IImu Kelautan Universitas Sam Ratulangi, Manado, menggunakan transportasi mobil yang memakan waktu \pm 3 jam dari lokasi pengambilan sampel.

\section{Persiapan Pakan}

Pakan kerang mutiara yang digunakan sebagai perlakuan dalam penelitian ini, berbahan dasar ikan mentah dari jenis ikan Deho (Euthynnus affinis). Ikan tersebut masih dalam keadaan segar yang didapatkan dari pasar ikan lokal terdekat. Ikan segar ini selanjutnya diolah sesuai dengan prosedur pengolahan ikan mentah untuk pemeliharaan organisme planktonik, yang sudah dipatenkan dengan nomor paten P00201609066 oleh Rumengan dkk., (2016) dan paten nomor P14201802692 oleh wullur dkk., (2018). Sebanyak 0,18 hingga 0,28 gram daging ikan mentah tersebut kemudian dimasukkan ke masing-masing kantung, direndam selama 24 jam ke dalam beberapa jenis larutan probiotik sesuai perlakuan penelitian. Pakan ikan mentah tersebut selanjutnya siap diberikan kepada larva kerang mutiara, dengan cara memasukkan kantung pakan ke dasar media pemeliharaan.

\section{Pelaksanaan Penelitian}

Wadah plastik transparan berkapasitas 1 liter untuk pemeliharaan larva kerang mutiara, telah disiapkan sebanyak 15 buah. Sebelum digunakan, wadah pemeliharaan ini terlebih dahulu dicuci dengan air dikering-anginkan, kemudian diisi dengan air laut bersalinitas 35 ppt sebanyak $700 \mathrm{ml}$. Media pemeliharaan tersebut kemudian ditempatkan pada ruangan bersuhu antara $25-26^{\circ} \mathrm{C}$. Masing - masing wadah pemeliharaan diberi aerasi dengan kecepatan berkisar 0,66 $\mathrm{ml} / \mathrm{min}$. Pelaksanaan penelitian dimulai dengan menginokulasikan larva kerang mutiara ke dalam masing-masing wadah pemeliharaan dengan kepadatan 33 ind $/ \mathrm{ml}$. Larva kerang mutiara tersebut, selanjutnya diberikan pakan sesuai dengan perlakuan penelitian, yaitu: 1).Ikan mentah yang direndam dengan produk probiotik EM4 (EM4), 2).Ikan mentah yang direndam dengan produk probiotik probio fm (Probio FM) 3). Ikan mentah yang direndam dengan probiotik Starbio f9 (Starbio F9), 4).Plankton, 5).tanpa pemberian pakan (No Food). Pengamatan dilakukan dengan mengambil cuplikan sampel sebanyak 3 $\mathrm{ml}$ yang dilakukan setiap 2 hari sekali selama 14 hari. Larva yang diperoleh 
dari masing - masing cuplikan sampel tersebut selanjutnya diukur panjang dan tinggi cangkang larva. Pada akhir penelitian yaitu pada hari ke - 14 pemeliharaan, larva yang ada pada masing - masing wadah selanjutnya dipanen, kemudian jumlah larva kerang mutiara yang hidup dihitung dan bagian panjang dan tinggi tubuh larva diukur.

\section{Parameter yang diamati}

Adapun yang menjadi parameter pengamatan dalam penelitian ini adalah ukuran panjang dan tinggi cangkang larva serta pangkal cangkang larva kerang mutiara sesuai dengan perlakuan dan waktu pemeliharaan serta sintasan larva yang didapat pada akhir masa pemeliharaan.

\section{Analisis Data}

Data hasil pengukuran panjang cangkang, tinggi cangkang dan pangkal cangkang larva diolah dan ditampilkan dalam bentuk grafik ukuran larva berdasarkan waktu untuk setiap perlakuan. Estimasi sintasan larva dalam setiap wadah pemeliharaan dilakukan dengan memplotkan data hasil pengamatan sintasan yang diperoleh setiap 2 hari dalam bentuk grafik batang.

\section{HASIL DAN PEMBAHASAN}

\section{Morfometri Larva Kerang Mutiara}

Panjang tubuh larva kerang mutiara $P$. maxima yang diamati setiap 2 hari selama 14 hari percobaan untuk setiap perlakuan dalam penelitian ini di tampilkan pada Gambar 2. Rata-rata panjang cangkang larva kerang mutiara berada pada kisaran antara 61.9 $194.47 \mu \mathrm{m}$ selama 14 hari pemeliharaan. Hasil pengukuran panjang larva setiap perlakuan terlihat adanya kecenderungan setiap ukuran panjang yang lebih stabil pada larva yang diberikan perlakuan probiotik dengan larva yang diberikan pakan mikroalga yang cenderung bervariasi.

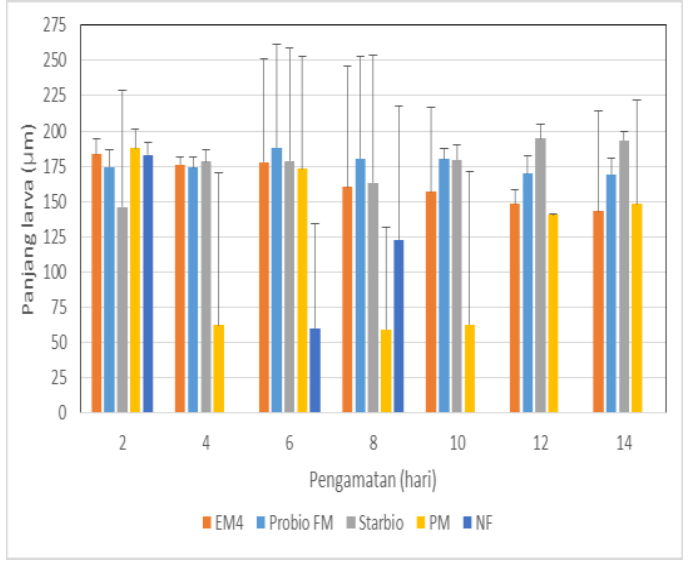

Gambar 2. Ukuran panjang cangkang larva kerang mutiara (Pinctada maxima) yang dipelihara menggunakan pakan ikan mentah yang direndam dengan produk probiotik EM4 (EM4), Probio FM (Probio FM), Starbio f9(Starbio), serta menggunakan pakan mikroalga jenis Isochrysis. sp dan perlakuan tanpa pemberian pakan (NF), selama 14 hari.

Hasil penelitian ini mengindikasikan bahwa larva kerang mutiara yang diberikan pakan ikan mentah, dapat memanfaatkan nutrisi yang diproduksi dari proses penguraian ikan mentah yang direndam pada beberapa produk probiotik sesuai dengan perlakuan, hal mana juga teramati pada larva yang diberi pakan mikroalga Isochrysis sp., yang merupakan pakan yang sering digunakan dalam pemeliharaan larva kerang mutiara. Berbeda halnya dengan larva kerang mutiara pada perlakuan tanpa pakan, ukuran panjang larva pada perlakuan ini sangat variative bahkan populasi larva semakin berkurang hingga tidak ada lagi yang mampu bertahan hidup. hingga hari ke-14. Pertumbuhan panjang larva dalam penelitian menunjukkan kemiripan dengan laporan penelitian dari Winanto (2009), dimana ukuran panjang berkisar antara 106 - $165 \mu \mathrm{m}$ pada periode umur larva yang sama.

Ukuran tinggi cangkang larva kerang mutiara $P$. maxima yang diamati setiap 2 hari selama 14 hari percobaan untuk setiap perlakuan dalam penelitian ini di tampilkan pada Gambar 3. Secara 
umum, rata-rata tinggi cangkang larva kerang mutiara berada pada kisaran antara $59.46-216.81 \mu \mathrm{m}$ selama 14 hari pemeliharaan. Hasil pengukuran tinggi cangkang larva dari setiap perlakuan menunjukkan adanya kecenderungan ukuran tinggi yang lebih stabil antara larva yang ada pada perlakuan pakan ikan mentah yang direndam dengan produk probiotik, serta menunjukan respons yang hampir sebanding dengan perlakuan pakan mikroalga terutama pada hari-hari terakhir pengamatan.

Larva pada perlakuan tanpa pemberian pakan, terobservasi hanya pada hari ke2, 6, dan 8 pemeliharaan. Tidak terobservasinya larva pada hari pengamatan ke 4, 10 dan 12 diduga karena keberadaan larva dalam perlakuan ini yang semakin sedikit sehingga tidak tersampling pada saat pengambilan cuplikan sampel. Hasil pengukuran tinggi cangkang larva kerang mutiara pada penelitian ini, mirip dengan yang dilaporkan oleh Winanto (2009) menunjukkan di kisaran angka tinggi cangkang pada $95-155 \mu \mathrm{m}$.

Secara umum, rata-rata lebar pangkal cangkang larva kerang mutiara berada pada kisaran antara $21-88.1 \mu \mathrm{m}$ selama 14 hari pemeliharaan. Pada pengamatan, ukuran pangkal cangkang larva yang cenderung berbeda antara perlakuan probiotik dengan pakan mikroalga. Namun pada perlakuan probiotik terdapat lebar pangkal yang hampir setara/stabil diantara ketiga perlakuan probiotik. Hal ini dapat dilihat pada pengamatan selama 14 hari, jarak rataan lebar pangkal cangkang yang tidak terlalu berbeda yang memiliki rataan yang hampir sama. Hal ini menunjukkan bahwa larva kerang mutiara yang dikombinasikan dengan produk probiotik dimanfaatkan oleh larva sebagai sumber nutirisi larva untuk berkembang dan bertumbuh. Hasil pengukuran ini menunjukkan bahwa pertumbuhan lebar pangkal cangkang larva mengalami kondisi yang cenderung stabil dan tidak telalu berbeda pada perlakuan untuk setiap

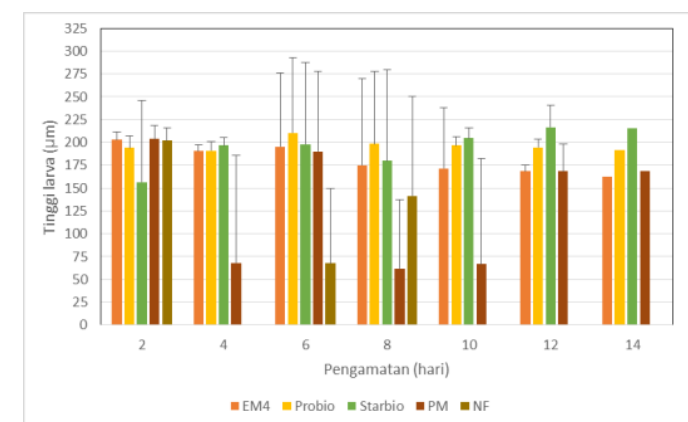

Gambar 3. Ukuran tinggi cangkang larva kerang mutiara (pinctada maxima) yang dipelihara menggunakan pakan ikan mentah yang direndam dengan produk probiotik EM4 (EM4), Probio FM (Probio FM), Starbio F9 (Starbio), serta menggunakan pakan murni (plankton) dan tanpa pakan (NF), selama 14 hari.

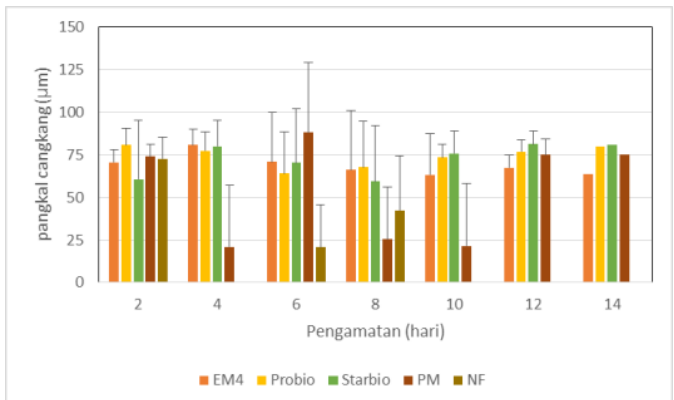

Gambar 4. Ukuran pangkal cangkang larva kerang mutiara (pinctada maxima) yang dipelihara menggunakan pakan ikan mentah yang direndam dengan produk probiotik EM4 (EM4), Probio FM (Probio FM), Starbio f9 (Starbio), serta menggunakan pakan murni (plankton) dan tanpa pakan (NF), selama 14 hari.

pengamatan, perlakuan pakan ikan mentah yang direndam dengan produk probiotik memberikan pertumbuhan lebar yang cenderung lebih baik dibandingkan perlakuan lainnya,

\section{Sintasan larva}

Sintasan atau jumlah larva P.maxima yang bertahan hidup hingga akhir periode selama 14 hari pengamatan ditampilkan pada Gambar 


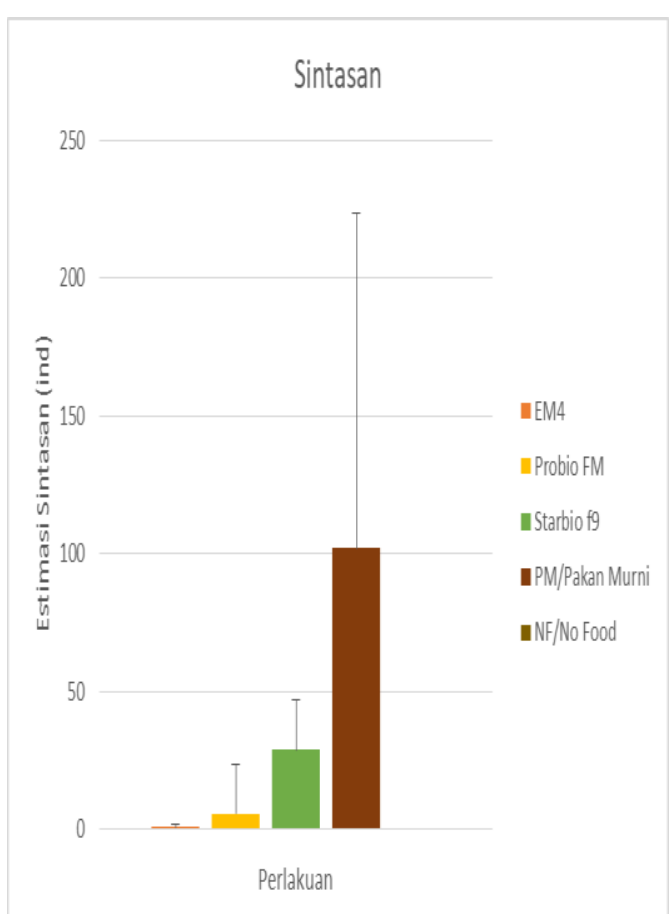

Gambar 5. Sintasan terakhir larva yang bertahan hidup, larva kerang mutiara Pinctada maxima yang dipelihara menggunakan pakan ikan mentah yang direndam dengan produk probiotik EM4 (EM4), Probio FM (Probio FM), Starbio f9 (Starbio), serta menggunakan pakan murni (plankton), dan tanpa pakan (NF) selama 14 hari.

5. Hasil penghitungan jumlah larva di akhir periode pemeliharaan untuk masing-masing perlakuan menunjukan sintasan larva tertinggi, terobservasi pada perlakuan pakan mikroalga dengan rata-rata jumlah larva yang bertahan hidup sebanyak $102 \pm 121.7$ larva. Selanjutnya rata-rata jumlah larva yang bertahan hidup semakin berkurang pada perlakuan pakan ikan mentah yang direndam dengan Starbio F9 (29 \pm 18.02 larva), Probio FM (5.6 \pm 1.52 larva) dan EM 4 (1.66 \pm 1larva) sedangkan untuk perlakuan tanpa pakan tidak ditemukan adanya larva yang mampu bertahan hidup hingga hari terakhir penelitian.

\section{KESIMPULAN}

Secara umum, penelitian ini menunjukan bahwa larva kerang mutiara dapat memanfaatkan mikroalga serta ikan mentah yang dikombinasikan dengan produk probiotik sebagai sumber nutrisi larva untuk pertumbuhan dan perkembangan hidupnya. Pengaruh penggunaan jenis-jenis pakan tersebut terhadap pertumbuhan dan sintasan larva dapat disimpulkan sebagai berikut:1. Pertumbuhan larva kerang mutiara (panjang, tinggi, serta pangkal cangkang) yang dipelihara menggunakan pakan ikan mentah yang direndam dengan produk probiotik hampir sebanding dengan larva yang dipelihara menggunakan pakan mikroalga. 2. Sintasan larva kerang mutiara yang paling tinggi terobservasi pada perlakuan pakan mikroalga, kemudian dikuti oleh larva pada perlakuan pakan ikan mentah dengan probiotik sedangkan larva pada perlakuan tanpa pemberian pakan tidak lolos hidup hingga akhir penelitian hari ke-14.

\section{UCAPAN TERIMA KASIH}

Terimakasih disampaikan kepada Kementrian Riset, Teknologi dan Pendidikan Tinggi, Republik Indonesia dan Universitas Sam Ratulangi, Manado, yang telah membiayai penelitian ini dalam skema Penelitian Pengembangan Unggulan Perguruan Tinggi (PPUPT), tahun anggaran 2018.

\section{DAFTAR PUSTAKA}

Ponder, F.P., Lindberg, D.R. 2008. Phylogeny and Evolution of the Mollusca. University of California Press. 479 hal.

Sujoko, A. 2010. Membenihkan Kerang Mutiara. Insan Madani. Yogyakarta.

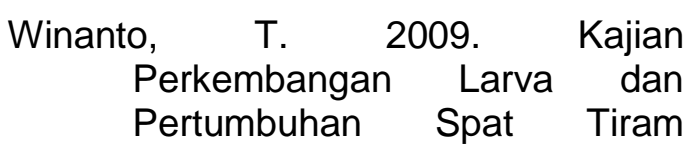


Mutiara Pinctada maxima

(Jameson) pada Kondisi

lingkungan pemeliharaan

berbeda. Sekolah Pascasarjana

Institut Pertanian Bogor, Bogor.

208 halaman.

Winanto, T. 2004. Memproduksi Benih Tiram Mutiara. P.T. Panebar Swadaya, Jakarta. Seri Agribisnis. 95 hal.

Wullur, S., Sakakura, Y.,Hagiwara, A. 2009. The Minute Monogonont Rotifer Proales similis de Beauchamp: Culture and Feeding to small Mouth Marine Fish Larvae. Aquaculture, 293:62-67. 